ТЕОРЕТИЧНЕ ОБҐРУНТУВАННЯ СТРУКТУРНО-ФУНКЦІОНАЛЬНОЇ МОДЕЛІ РОЗВИТКУ ПРОФЕСІЙНОГО ПОТЕНЦІАЛУ МАЙБУТНІХ УЧИТЕЛІВ ІНОЗЕМНИХ МОВ У ПРОЦЕСІ ФАХОВОЇ ПІДГОТОВКИ

\title{
THEORETICAL FOUNDATION OF THE STRUCTURAL-FUNCTIONAL MODEL OF DEVELOPING PROFESSIONAL POTENTIAL OF FUTURE TEACHERS OF FOREIGN LANGUAGES IN THE TEACHER TRAINING PROCESS
}

У статті здійснено теоретичне обгрунтування структурно-срункціональної моделі розвиткупросесійного потенціалумайбутніх учителів іноземних мов у процесі фрахової підготовки. Підсумовано, що вивчення такої моделі відображає фундаментальні властивості об'єкта-прототипу, допомагає виявити ключові ознаки досліджуваних процесів, дає змогу проаналізувати їхню динаміку, виявити структурно-срункціональні, причинно-наслідкові та генетичні зв'язки між усіма складниками. Узагальнено, що розроблена модель обов'язково містить прогностичний аспект, пов'язує інфоормаційний образ теперішнього з теоретичним образом майбутнього. Модель та оригінал завжди перебувають в об'єктивній відповідності. Теоретично обгрунтовано бачення процесу розвитку професійного потенціалу майбутніх учителів іноземних мов у прочесі фрахової підготовки в авторській структурно-фрункціональній моделі. Модель характеризується цілісністю, взаємодією ії елементів, частин, зв'язками і відношеннями, що зумовлюють ії структуру, взаємодію із середовищем, системами нижчого вищого порядку, щодо яких вона виступає як частина. Системне моделювання передбачало не лише проєктування, але й визначення шляхів упровадження пропоновано структурно-срункціональної моделі розвитку профресійного потенціалу майбутніх учителів іноземних мов у прочесі фрахової підготовки в освітню практику закладів вищої освіти України.

У моделі відображено структурно-фрункціональну взаємодію та взаємозв'язок таких основних компонентів: цільового, метологічно-концептуального, критеріального, результативно-аналітичного. У моделі відображено основні ознаки, структурно-срункціональні та причинно-наслідкові зв'язки між елементами аналізованих процесів розвитку професійного потенціалу майбутніх учителів іноземних мов у процесі фрахової підготовки. У моделі відображено, що на основі дотримання специорічних принципів організації дослідження, реалізації наукових підходів івизначених педагогічних умов результатом $\epsilon$ ссрормований профресійний потенціал майбутніх учителів іноземних мов.

Ключові слова: потенціал, просресійний потенціал, компонент, блок, модель, струк- турно-срункціональна модель, майбутні вчителі іноземних мов.

The article provides the theoretical foundation of the structural and functional model of professional development of future teachers of foreign languages in the teacher training process. It is pointed out that the study of such a model reflects the fundamental properties of the prototype object, helps to identify the key features of the studied processes, and allows analyzing their dynamics, to identify structural-functional, causal inference and genetic links between all the components. In general, the developed model necessarily contains a prognostic aspect and connects the informational features of the present with the theoretical feature of the future. The model and the original are always in objective agreement. The understanding of the process of developing professional potential of future teachers of foreign languages in the teacher training process in the author's structuralfunctional model is theoretically substantiated. The model is characterized by integrity, interaction of its elements, parts, connections and relations that determine its structure, interaction with the environment, lower and higher order systems in relation to which it acts as a part. The modeling system provided not only design, but also determination of ways of introducing the offered structural and functional model of developing professional potential of future teachers of foreign languages in the course of professional preparation in educational practice in institutions of higher education of Ukraine.

The model reflects the structural and functional interaction and the relationship of such main components as target, methodological, conceptual, criterial and effective-analytical components. The model provides the main features, structural-functional and causal links between the elements of the analyzed processes of professional development of future foreign language teachers in the teacher training process; moreover, it shows that based on the specific principles of research organization, implementation of scientific approaches and certain pedagogical conditions, the result is the formed professional potential of future foreign language teachers.

Key words: potential, professional potential, component, model, structural-functional model, future foreign language teachers.
Постановка проблеми в загальному вигляді. Сучасний етап економічного розвитку суспільства зумовив необхідність модернізації системи освіти. Основні зміни відображено в Законі «Про освіту» (2017р.), «Національній доктрині освіти України», у ключовій ресрормі Міністерства освіти і науки України «Нова українська школа», що стартувала 1 вересня 2018 року. Зроблена установка на підвищення уваги до якості освітніх послуг, на індивідуалізацію освітнього процесу та реалізацію компетентнісного підходу в підготовці педагогічних кадрів. Головним результатом модернізації школи має стати адекватність освіти школярів цілям випереджувального розвитку суспільства.

Процеси подальшого оновлення системи вищої освіти об'єктивно спрямовані насамперед на 
забезпечення потреб суспільства й держави у кваліфрікованих педагогах, що передбачає відповідні зміни в професійно-педагогічній підготовці, розвитку та саморозвитку особистості майбутнього вчителя. Важливим компонентом загального процесу розвитку професійної діяльності є професійне становлення особистості. Наразі однією з центральних проблем підготовки майбутніх учителів іноземної мови є дослідження професійного потенціалу як визначальної характеристики фрахівця, що дає змогу людині максимально виявити свої здібності й творчо опанувати професію.

Аналіз останніх досліджень і публікацій та виділення не вирішених раніше частин загальної проблеми. Перш ніж перейти до характеристики структурно-срункціональної моделі розвитку професійного потенціалу майбутніх учителів іноземних мов у процесі фрахової підготовки, зупинімося на тих теоретичних надбаннях, які стали підґрунтям для її розроблення. У нашому дослідженні враховувалися наукові підходи до проблеми моделювання процесу навчання загалом [6]; до аналізу процесу моделювання як ідеальної срази проєктування інноваційних педагогічних систем [11]; до моделювання процесу підготовки майбутніх фрахівців на різних етапах суспільного розвитку [8] і розроблення моделі структури особистості сучасного вчителя іноземної мови [1] та ін.

Однак у результаті проведення теоретичного аналізу не знайдено цілеспрямованих наукових розвідок дослідників у напрямі обґрунтування структурно-срункціональної моделі розвитку професійного потенціалу майбутніх учителів іноземних мов у процесі фахової підготовки, що визначено метою статті.

Виклад основного матеріалу. Відомо, що однією 3 основних категорій теорії пізнання, на якій ґрунтуються теоретичні й експериментальні методи наукового дослідження, $€$ моделювання динамічного процесу, що вивчається. Під моделлю (лат. modulus - міра, зразок) розуміється уявна або матеріально реалізована система, що відображає, відтворює або імітує будову і дію певного об'єкта дослідження (природного чи соціального), використовується для одержання нових знань про нього [5, с. 118], оскільки здатна змінювати його так, що її вивчення дає нову інфрормацію [2, с. 516]

Соціологи стверджують, що опосередковане вивчення окремих об'єктів, дослідження явищ і процесів за допомогою моделей визначається як метод моделювання. Процес створення моделі полягає в конструюванні з елементів (компонентів) цілісного абстрактного образу реальності 3 невідомими властивостями на основі гіпотези про сутність зв'язків між складовими частинами змодельованої системи. За таких умов модель виступає як об'єкт теоретичного кількісного та якісного дослідження, є джерелом емпіричних і теоретич- них знань. Найповніше пізнавальні можливості моделювання виявляються в застосуванні його як складової частини методу системного дослідження [10, с. 238].

У дисертації С. Мартиненко термін «модель» характеризується як певна система (взірець, приклад, образ, конструкція), що відображає певні властивості та взаємини з іншою системою, яка називається оригіналом і певною мірою заміщає їі. Дослідниця вказує, що в методології науки модель - аналог (схема, структура, знакова система) визначеного фррагмента природної або соціальної реальності, творіння людської культури, концептуально-теоретичного утворення - оригінальної моделі. Із гносеологічного погляду модель - це «представник», «замінник» оригіналу в пізнанні та практиці. Результати розроблення й дослідження моделі за певних умов, з'ясованих у логіці та методології, специфічних для різних галузей і типів моделей, поширюються на оригінал [7, с. 174].

Обґрунтовуючи теоретичні та методичні основи моделювання процесу профресійної підготовки фрахівця, Т. Ващик, В. Давидов і О. Рахімов визначають модель у зазначеному контексті як уявний об'єкт, що заміщує в дослідженні об'єкт-оригінал самого процесу навчання [3, с. 62-83]. Проте, визначаючи специфріку моделювання педагогічних ситуацій, науковці зазначають, що в такому процесі не окреслюються особливості практичної реалізації самого методу моделювання і не виокремлюються риси, що відрізняють модель від змодельованого об'єкта або явища [11, с. 163-164].

Зазвичай метод моделювання використовують у тому разі, коли йдеться про необхідність управління складною системою та про прогнозування результатів ії фрункціонування. На думку В. Вікторова, пізнавальний потенціал моделі виявляється лише за умови, коли вона сприяє отриманню нової інсрормації про об'єкт, який досліджується. Автор зазначає, що моделювання виконує цілий комплекс фуункцій: ілюстративну, пояснювальну, критеріальну, евристичну, прогностичну, перетворювальну. Адже досліджується не сам об'єкт, а штучна система, що перебуває в певній відповідності до об'єкта, який вивчається [4, с. 23].

Аналіз різних наукових підходів щодо визначення сутності освітянської моделі дав змогу С. Мартиненко узагальнити, що це:

- спосіб організації життєдіяльності навчального закладу;

- взірець, приклад (точніше образ) досвіду, у якому переосмислюється педагогічна діяльність і досвід у навчанні або учінні;

- тип альтернативної шкільної освіти й архітектура її конструкцій та нових форм;

- систематизована фрорма інноваційного експерименту; 
- концептуальне обґрунтування проєктивного режиму розвитку школи;

- організаційна система, яка транслює та розвиває культурні норми [7, с. 176].

Нам імпонує характеристика моделі за І. Мельничук, яка зазначає, що вивчення моделі відображає фрундаментальні властивості об'єктапрототипу, сприяє виявленню ключових ознак аналізованих процесів, дає змогу проаналізувати їхню динаміку, виявити структурно-орункціональні, причинно-наслідкові та генетичні зв'язки між його складниками. Важливим є те, що модель обов'язково містить прогностичний аспект, пов'язує інформаційний образ теперішнього з теоретичним образом майбутнього. Модель та оригінал завжди перебувають в об'єктивній відповідності. У процесі пізнання модель заміщає об'єкт, і сама стає об'єктом дослідження [8, с. 270].

У сучасній логіці й методології науки під моделлю розуміється аналог (схема, структура, знакова система) певного фррагмента природної або соціальної реальності, породження людської культури, концептуально-теоретичного уривку освіти. Отже, теоретико-методологічну основу моделювання процесу розвитку професійного потенціалу майбутніх учителів іноземних мов у процесі фрахової підготовки становили загальнонаукові та педагогічні положення про моделювання.

Теоретико-методологічні основи організації особистісно-професійного становлення майбутніх учителів іноземних мов у напрямі розвитку профресійного потенціалу в процесі фрахової підготовки базуються на реалізації сукупності положень обраних науково-педагогічних підходів (системного, компетентнісного, акмеологічного, аксіологічного, особистісного, діяльнісного). Оскільки важливою особливістю внутрішнього взаємозв'язку всіх зазначених підходів є їх доповнення один одного, то найбільшої ефективності вони набувають в інтеграції.

Авторське бачення процесу розвитку профресійного потенціалу майбутніх учителів іноземних мов у процесі фрахової підготовки в контексті нашого дослідження представлено в авторській структурно-фрункціональній моделі. Модель характеризується цілісністю, взаємодією її компонентів, елементів, частин, зв'язками, що зумовлюють її структуру, взаємодію із середовищем, системами нижчого і вищого порядку, щодо яких вона виступає як частина. Системне моделювання передбачало не лише проєктування, але й визначення шляхів упровадження пропонованої методики розвитку професійного потенціалу майбутніх учителів іноземних мов у процесі фрахової підготовки в освітню практику закладів вищої освіти (ЗВО) України. У моделі відображено структурно-фрункціональну взаємодію та взаємозв'язок таких основних компонентів-блоків: цільового; методологічно-кон- цептуального; критеріального; результативноаналітичного. Передбачалося, що в моделі буде відображено основні ознаки, структурно-функціональні та причинно-наслідкові зв'язки між аналізованими процесами розвитку професійного потенціалу майбутніх учителів іноземних мов у процесі фрахової підготовки.

У моделі відображено поєднання мети й результату забезпечення розвитку професійного потенціалу майбутніх учителів іноземних мов. Для досягнення поставленої мети було визначено такі педагогічні умови:

1) фрормування позитивного «Я-образу» професіонала у свідомості студентів шляхом використання методу кейсів;

2) забезпечення фрормування професійного світогляду майбутніх учителів іноземних мов на основі розширення змісту навчальних дисциплін інорормацією міждисциплінарного характеру;

3) використання освітнього контексту профресійної підготовки майбутніх учителів іноземних мов як середовища для формування профресійного потенціалу;

4) організація рефлексивно-творчої навчальної діяльності студентів.

У реалізації визначених педагогічних умов використовувалися системний, компетентнісний, акмеологічний, аксіологічний, особистісний, діяльнісний наукові підходи до розвитку професійного потенціалу майбутніх учителів іноземних мов у процесі фрахової підготовки. Також у моделі конкретизовано принципи дослідження, які вказують на провідні правила його організації та відображають психолого-педагогічні закономірності особистісно-професійного розвитку. Це такі принципи:

- цілісності розвитку професійного потенціалу майбутніх учителів іноземних мов;

- єдності педагогічно організованого процесу розвитку і саморозвитку особистості;

- діагностичної основи і рефрлексії особистіснопросресійного розвитку.

Закономірності вказують на спрямованість дослідницького процесу на дотримання принципів саморозвитку студентів, організації систематичного зворотного зв'язку й самоконтролю в професійній комунікації.

3 погляду компетентнісного підходу головною цінністю процесу розвитку професійного потенціалу майбутніх учителів іноземних мов у процесі фахової підготовки є компетентна особистість, носій гуманітарної свідомості, суб'єкт «цілісної людської діяльності». Психолого-педагогічний механізм фрормування компетентної особистості $€$ складною єдністю когнітивного, предметно-практичного (професійного) й особистісного досвіду. Окреслений механізм є транслятором особистісно-профресійного розвитку й допомагає активізувати самостійність і активність особистості 
у виробленні власного методу, ціннісної основи майбутньої педагогічної діяльності, професійних установок тощо. Сформованість профресійного потенціалу майбутніх учителів іноземних мов визначалася за конкретними критеріями. Зміст показників кожного критерію встановлювався за чотирма рівнями: високим, середнім, задовільним і низьким.

Результативно-аналітичний блок моделі базується на аналізі результатів констатувального етапу експерименту, встановленні результатів у процесі проведення формувального етапу експериментального дослідження, порівнянні визначених показників для обґрунтування ефективності запропонованої структурно-фрункціональної моделі розвитку професійного потенціалу майбутніх учителів іноземних мов у процесі фрахової підготовки. Для перевірки достовірності отриманих результатів використовувалися методи математичної статистики.

Висновки. Авторське бачення процесу розвитку профресійного потенціалу майбутніх учителів іноземних мов у процесі фрахової підготовки В контексті нашого дослідження представлено в авторській структурно-фрункціональній моделі, яка характеризується цілісністю, взаємодією всіх складників, що відображають її структуру, взаємодією із середовищем, системами нижчого і вищого порядку, щодо яких вона виступає як частина. У моделі відображено структурно-срункціональну взаємодію та взаємозв'язок цільового, методологічно-концептуального, критеріального й результативно-аналітичного компонентів-блоків.

Оскільки системне моделювання передбачало не лише проєктування, але й визначення шляхів упровадження пропонованої методики розвитку професійного потенціалу майбутніх учителів іноземних мов у процесі фрахової підготовки в освітню практику ЗВО України, перспективи подальших наукових розвідок вбачаємо в репрезентуванні методичних особливостей реалізації розробленої структурно-фрункціональної моделі.

\section{БІБЛІОГРАФІЧНИЙ СПИСОК:}

1. Бабенко Т. Формування особистості менеджера освіти. Директор школи. 2007. № 21-22. С. 3-56.

2. Великий тлумачний словник сучасної української мови / уклад. і голов. ред. В.Т. Бусел. Київ ; Ірпінь : ВТФ «Перун», 2009. 1736 с.

3. Ващик Т. Принципи моделювання педагогічного процесу. Педагогіка і психологія формування творчої особистості : проблеми і пошуки. 2005. Вип. 34. C. $163-170$.

4. Вікторов В. Нові моделі управління освітою. Вища освіта України. 2005. № 2. С. 66-71.

5. Гагин Ю. Концептуальный словарь-справочник по педагогической акмеологии. Санкт-Петербург : СПбГУПМ, 1998. 178 с.

6. Загвязинський В. Методология и методы психолого-педагогического исследования. Москва : Издательский центр «Академия», 2003. 208 с.

7. Мартиненко С. Система підготовки вчителя початкових класів до діагностичної діяльності : дис. ... д-ра пед. наук : спец. 13.00.04. Київ, 2009. 447 с.

8. Мельничук І. Теорія і практика професійної підготовки майбутніх соціальних працівників засобами інтерактивних технологій : дис. ... д-ра пед. наук : 13.00.04. Тернопіль, 2011. 584 с.

9. Мурованная Н. Целевой подход как основа концепции педагогического руководства развитием профессиональной компетенции в институтах последипломного педагогического образования. Витоки педагогічної майстерності. 2009. Вип. 6. C. $242-246$.

10. Новиков А. Методология : словарь системь основных понятий. Москва : Либроком, 2013. 208 с.

11. Фурман А. Методологічне обґрунтування багаторівневості парадигмальних досліджень у соціальній психології. Психологія і суспільство. 2012. № 4. C. 78-125. 